\title{
Exponential increase of signal crayfish in running waters in Sweden - due to illegal introductions?
}

\author{
P. Bohman ${ }^{(1)}$, E. Degerman ${ }^{(1)}$, L. Edsman ${ }^{(1)}$, B. Sers ${ }^{(1)}$ \\ Received January 17, 2011 \\ Revised April 7, 2011 \\ Accepted April 29, 2011
}

Key-words:

Pacifastacus leniusculus,

Astacus

astacus, illegal introductions, fisheries legislation, electrofishing

\section{ABSTRACT}

Sweden has only one indigenous species of crayfish, the noble crayfish (Astacus astacus, Fabricius). There has been a steady decline of noble crayfish populations in Sweden since 1907, mainly due to the crayfish plague. To substitute the noble crayfish fishery lost, the Swedish government launched a large-scale introduction of the signal crayfish (Pacifastacus leniusculus Dana). Today, the signal crayfish is regarded as a chronic carrier of the crayfish plague, and an expansion of the species may seriously threaten the noble crayfish. This paper examines the decrease of noble crayfish populations, and the concurrent expansion of signal crayfish in running waters. Data from the Swedish Electrofishing RegiSter (SERS) was used. We found that in 1980-1984 the noble crayfish occurred in $4.5 \%$ of the studied river sections. In 2008-2009 the occurrences had decreased to $1.9 \%$. In contrast, the signal crayfish had increased in occurrence, from $0.2 \%$ (1980-1984) to $11.8 \%$ in (2008-2009). We studied the number of stocking permits for signal crayfish introductions, and the available signal crayfish population from the open fishery in Lake Vättern, as possible causes of this expansion. A negative correlation between stocking permits and increased occurrence in streams, and a positive correlation between the availability of crayfish in Lake Vättern and the occurrence in streams was found. This suggests that the expansion of signal crayfish may be due to illegal introductions, further endangering the endemic noble crayfish.

\section{RÉSUMÉ}

Développement exponentiel de l'écrevisse signal dans les eaux courantes suédoises est-ce dû aux introductions illégales?

Mots-clés:
Pacifastacus
leniusculus,
Astacus
astacus,
introductions
illégales,
législation
des pêches,
pêche électrique

La Suède n'a qu'une espèce d'écrevisse indigène, l'écrevisse noble (Astacus astacus, Fabricius). Les populations d'écrevisse noble sont en déclin régulier depuis 1997, principalement à cause de la peste de l'écrevisse. Pour remplacer cette perte dans les pêcheries, le gouvernement suédois a entrepris une introduction à grande échelle de l'écrevisse signal (Pacifastacus leniusculus Dana). Aujourd'hui, l'écrevisse signal est considérée comme porteur chronique de la peste de l'écrevisse et une expansion de cette espèce peut nuire sérieusement à l'écrevisse noble. Cet article étudie le déclin des populations de l'écrevisse noble et l'expansion simultanée de l'écrevisse signal dans les eaux courantes. Les données du registre suédois des pêches électriques (SERS) ont été analysées. En 1980-1984

(1) Institute of Freshwater Research, Swedish Board of Fisheries, 17893 Drottningholm, Sweden, patrik.bohman@fiskeriverket.se 
l'écrevisse noble était présente dans 4,5\% des sections de rivière étudiées. En 2008-2009, l'occurrence est abaissée à 1,9\%. Par ailleurs, l'occurrence de l'écrevisse signal est passée de 0,2 \% (1980-1984) à 11,8\% en (2008-2009). Nous avons étudié le nombre d'autorisations d'introductions d'écrevisse signal et la disponibilité d'écrevisses depuis la pêcherie du lac Vättern, comme causes possibles de son expansion. Une corrélation négative entre les autorisations d'introductions et l'augmentation de présence dans les cours d'eau et une corrélation positive entre la disponibilité des écrevisses du lac Vättern et la présence dans les cours d'eau ont été trouvées. Cela suggère que l'expansion de l'écrevisse signal est probablement due aux introductions illégales, menaçant encore plus l'écrevisse noble endémique.

\section{INTRODUCTION}

Sweden has only one indigenous species of crayfish, the noble crayfish (Astacus astacus, Fabricius). There has been a steady decline of noble crayfish populations in Sweden since 1907 (Fiskeriverket and Naturvårdsverket, 1998), when the crayfish plague first occurred (Arwidsson, 1920; Alm, 1929). The plague (Aphanomyces astaci, Schikora) is a parasite on crayfish and is spread by infected crayfish and spores in the water or on wet equipment. Infected populations of native crayfish may become extinct within a few weeks (Alm, 1929; Unestam, 1972). Although the main factor for the decline of noble crayfish populations has been the crayfish plague, acidification and habitat degradation have also been contributing factors (Appelberg, 1984; Edsman and Schröder, 2009). Since the Swedish market for freshwater crayfish is highly attractive, the Swedish government introduced another crayfish species - the signal crayfish (Pacifastacus leniusculus Dana). The first introductions were made in the 1960s and the idea was to substitute the noble crayfish fishery lost, mostly due to the crayfish plague. It was also assumed that the signal crayfish would fill the ecological niche once held by the noble crayfish, since the species resembled the noble crayfish in both morphology and ecology (Fjälling and Fürst, 1985). From 1969 to 1994 a large number of signal crayfish were introduced in the southern and central parts of Sweden. The signal crayfish is, however, regarded as a chronic carrier of the crayfish plague (Unestam, 1972; Söderhäll and Cerenius, 1999; Dieguez-Uribeondo et al., 2006; Dieguez-Uribeondo, 2009), although it may also be subjected to acute plague when stressed (Cerenius et al., 2002). This implies that noble crayfish and signal crayfish seldom coexist in the same water, since the population of noble crayfish often will be fatally infected by the plague (Fiskeriverket and Naturvårdsverket, 1998). It has been shown that the large-scale introduction of signal crayfish has had a severe negative impact on the noble crayfish populations in Sweden, by further accelerating the spread of plague (Bohman et al., 2006).

The noble crayfish has gradually disappeared from many regions in the southern and central parts of Sweden. Today, the initial noble crayfish populations have decreased to $2-3 \%$ (less than 1000 populations) compared to their original numbers in early 1900 (Lowery and Holdich, 1988; Bohman et al., 2006; Edsman and Schröder, 2009). Since many noble crayfish populations are marginalised in these areas, one needs to go north of River Dalälven to find more stable populations. The river works as a judicial border, since introductions have never been allowed north of this river. In spite of this, recent data show that even these northern populations are threatened by illegal introductions (Bohman and Edsman, submitted).

In order to protect wild stocks and prevent spreading of fish and crayfish diseases, a permit for stocking of fish, including crayfish, has been prescribed in the Swedish fisheries legislation since 1954. The permits are managed by the fisheries officers at the regional authorities (Sweden's 21 County Administrations). Up until 1994 the regulations for introducing signal crayfish were liberal, resulting in a large number of waters being stocked with signal crayfish in the central and southern parts of Sweden (1983-1994). Over 3000 stocking permits had been given by 1994 (Häggström, 1994). In 1994, the regulations were restricted and stocking 
was prohibited in watersheds lacking signal crayfish, and watersheds having stocks of noble crayfish. In 2001, in addition to the previous legislation, it was forbidden to stock signal crayfish in watersheds where no previous licenses had been given.

In spite of regulatory attempts, the number of waters inhabiting signal crayfish has steadily increased the last 30 years (Bohman et al., 2006, Degerman et al., 2009), nowadays mainly due to illegal introductions (Bohman and Edsman, to appear). Myths regarding the signal crayfish as a "superior" species compared to the noble crayfish are probably the main cause for these illegal introductions (Edsman, 2000, 2003; Taugbol, 2004). No evidence exist today that these myths have any substantial value (Edsman, 2010). Instead, the risk to ruin healthy noble populations due to spread of crayfish plague is imminent (Edsman and Schröder, 2009). This paper examines the decrease of noble crayfish populations, and the concurrent expansion of signal crayfish in running waters. Considering the current situation in Sweden, it is likely that the signal crayfish is expanding in running waters due to illegal introductions of the species. We studied the number of stocking permits for signal crayfish introductions as a possible alternative cause of this expansion. We also investigated the relationship between catches of signal crayfish in the second largest lake in Sweden and the increase of signal crayfish occurrences. This lake is the only lake in the country where the fishery is open to all Swedish citizens.

\section{MATERIALS AND METHODS}

The Swedish Board of Fisheries is data host for several national databases. The main database for crayfish information is the Swedish Crayfish Database (SCD), which holds data on crayfish occurrences, test fishings, and registered crayfish plague outbreaks. The Swedish Board of Fisheries also manages the Swedish Electrofishing RegiSter (SERS), which is a monitoring database that consists of results from electrofishing in running waters. In this study, only data from SERS are used, and thus only includes crayfish occurrences in running waters. Electrofishing is a method where electric current (direct current) is used to catch fish and crayfish. A permit from the County Administration is needed to execute electrofishing, and reporting to SERS is mandatory. Electrofishing is carried out according to recommendations in Bohlin et al. (1989), and all fish and crayfish species are caught and registered.

All registered electrofishing occasions included in SERS 1980-2009 ( $n=43189$ records) have been analysed. Yearly data was grouped in periods of 2-5 years (Table I), and 500 electrofishing occasions were randomly chosen from each group. This was then repeated ten times, and the mean occurrence and standard deviation (bootstrapping) were calculated for both noble crayfish and signal crayfish. Crayfish not taxonomically categorized as a specific species ( $0.4 \%$ of all occurrences) have been excluded. For each period, the occurrences of noble and signal crayfish have been matched with a paired $t$-test. A trend analysis of mean occurrence over time was calculated using exponential regression. Crayfish occurrences for the different periods have been matched with variance analysis (Anova).

Data on the number of permits for introductions of signal crayfish for the study period was collected through a questionnaire to the regional fisheries officers at the County Authorities $(n=21)$. The relationship between the numbers of permits given and the occurrence of signal crayfish was tested by bivariate correlation (Spearman Rank Correlation).

Catch data from the commercial fishermen's logbooks in Lake Vättern was also used and the relationship between catch and the occurrence of signal crayfish was tested by bivariate correlation (Spearman Rank Correlation).

\section{RESULT AND DISCUSSION}

According to the Swedish Electrofishing RegiSter (SERS), the noble crayfish was found in southern Sweden and along the East coast of Norrland (northern Sweden), 1980-2009. The northernmost occurrence was registered in the river of Torneälv (Kukkolaforsen). On the other 


\section{Table I}

Mean occurrence (\%), standard deviation (S.d.), and descriptive statistics for the noble crayfish and signal crayfish in the Swedish Electrofishing RegiSter (SERS), 1980-2009. The occurrence for both species has been matched with paired t-test.

\section{Tableau I}

Occurrence moyenne (\%), déviation standard (S.d.) et statistiques descriptives de l'écrevisse noble et de l'écrevisse signal dans le registre suédois des pêches électriques (SERS), 1980-2009. L'occurrence des deux espèces a été comparée par test $t$-données appariées.

\begin{tabular}{|c|c|c|c|c|c|c|c|}
\hline \multirow[t]{2}{*}{ Period } & \multicolumn{2}{|c|}{ Noble crayfish } & \multicolumn{2}{|c|}{ Signal crayfish } & \multirow{2}{*}{$\begin{array}{l}\text { Fishing } \\
\text { occasions }\end{array}$} & \multirow{2}{*}{$\begin{array}{l}\text { Paired } \\
t \text {-test }\end{array}$} & \multirow{2}{*}{$\begin{array}{c}\% \text { Signal crayfish } \\
\text { of total }\end{array}$} \\
\hline & Mean & S.d. & Mean & S.d. & & & \\
\hline $1980-1984$ & 4.5 & 0.6 & 0.2 & 0.2 & 1100 & $<0.001$ & 4.3 \\
\hline 1985-1989 & 4 & 0.5 & 0.5 & 0.4 & 3321 & $<0.001$ & 11.1 \\
\hline 1990-1991 & 1.5 & 0.4 & 0.5 & 0.2 & 3030 & $<0.001$ & 25 \\
\hline 1992-1993 & 1.3 & 0.3 & 1.2 & 0.5 & 3161 & n.s. & 48 \\
\hline 1994-1995 & 2.2 & 0.7 & 1.7 & 0.6 & 4040 & n.s. & 43.6 \\
\hline $1996-1997$ & 2.1 & 0.6 & 2 & 0.5 & 3733 & n.s. & 48.8 \\
\hline 1998-1999 & 3 & 0.8 & 3 & 0.8 & 3799 & n.s. & 50 \\
\hline $2000-2001$ & 1.9 & 0.5 & 6.2 & 0.9 & 3732 & $<0.001$ & 76.5 \\
\hline $2002-2003$ & 2.2 & 0.4 & 8.9 & 1.7 & 4274 & $<0.001$ & 80.2 \\
\hline 2004-2005 & 1.6 & 0.5 & 6.8 & 1.2 & 3832 & $<0.001$ & 81 \\
\hline 2006-2007 & 1.6 & 0.5 & 10.4 & 1.1 & 4591 & $<0.001$ & 86.6 \\
\hline 2008-2009 & 1.9 & 0.6 & 11.8 & 1.1 & 4576 & $<0.001$ & 86.1 \\
\hline
\end{tabular}

n.s.: Not significant.

hand, the signal crayfish was only found in southern Sweden, from the River Gavleån and down south.

In 1980-1984, the noble crayfish occurred in $4.5 \%$ of the studied river sections. In 2008-2009 the occurrence of the noble crayfish had decreased to $1.9 \%$ (Table I). The decrease in number of registered noble crayfish was significant when compared between the three periods 19801989, 1990-1999, and 2000-2009. The mean occurrence within the three periods were $4.5 \%$ (1980-1989), 2.0\% (1990-1999), and 1.8\% (2000-2009, Anova, $F_{2,107}=91.2, p<0.001$ ). The levelling out of the occurrence curve from the 1990s (Figure 1) was mainly caused by the remaining populations in northern Sweden, as a large number of the southern noble crayfish populations have disappeared.

There has been a gradual increase in the number of signal crayfish in running waters (Figure 1). During 29 years of electrofishing, the occurrence of the signal crayfish has increased considerably, from $0.2 \%$ (1980-1983) to $11.8 \%$ (2008-2009). This trend has been exponential for the whole period (exponential regression, $r^{2}=0.96, F_{1.9}=250, p<0.001$ ). Between 1980 and 1991 the occurrence of signal crayfish was significantly lower than the noble crayfish, but from the year 2000 it has been significantly higher. Between 2006 and 2009 the signal crayfish was found in over $10 \%$ of the studied water sections.

The number of stocking permits increased significantly 1983-1994, during the later years of the large-scale introduction of the signal crayfish. When stricter regulations came in force by 1994, the number of permits decreased (Figure 2). From the year 2000 onwards less than 100 stocking permits were issued each year, while the same period showed a large increase in signal crayfish occurrences. We found an overall negative correlation between the number of permits and the occurrence of signal crayfish between the years 1980-2009 (Spearman rank $\rho=-0.875, p<0.001, n=12$ ). This is the opposite of what would be expected if the expansion of signal crayfish into new streams was caused by an increase of stocking permits. There may be a time lag between the introduction and the establishment of a reproducing population of crayfish. In this study, with electrofishing we record single individuals and not reproducing populations. Furthermore the time period covered in the study is so long that a time lag would not alter the general results. Thus an increase in stocking permits is not a likely cause for the increased occurrence of signal crayfish in streams. 


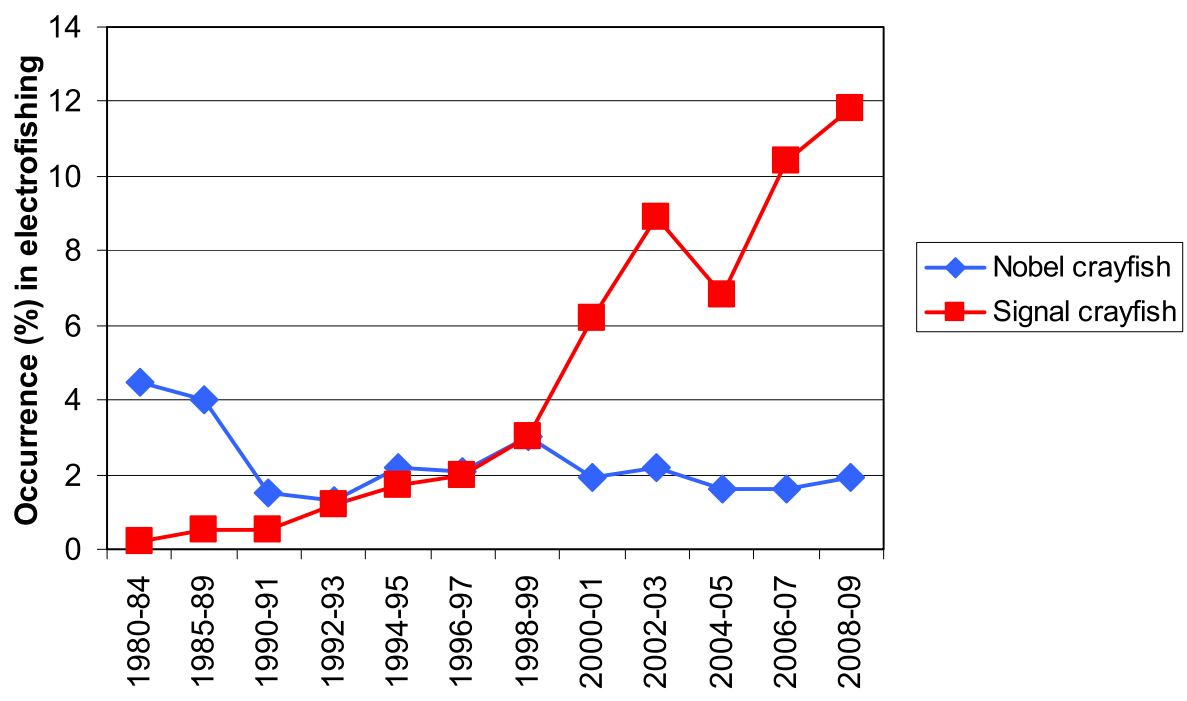

\section{Figure 1}

Occurrence (\%) of noble crayfish and signal crayfish in Swedish running waters 1980-2009, according to the Swedish Electrofishing RegiSter (SERS).

\section{Figure 1}

Occurrence (\%) de l'écrevisse noble et de l'écrevisse signal dans les eaux courantes suédoises en 1980-2009, selon le registre suédois des pêches électriques (SERS).

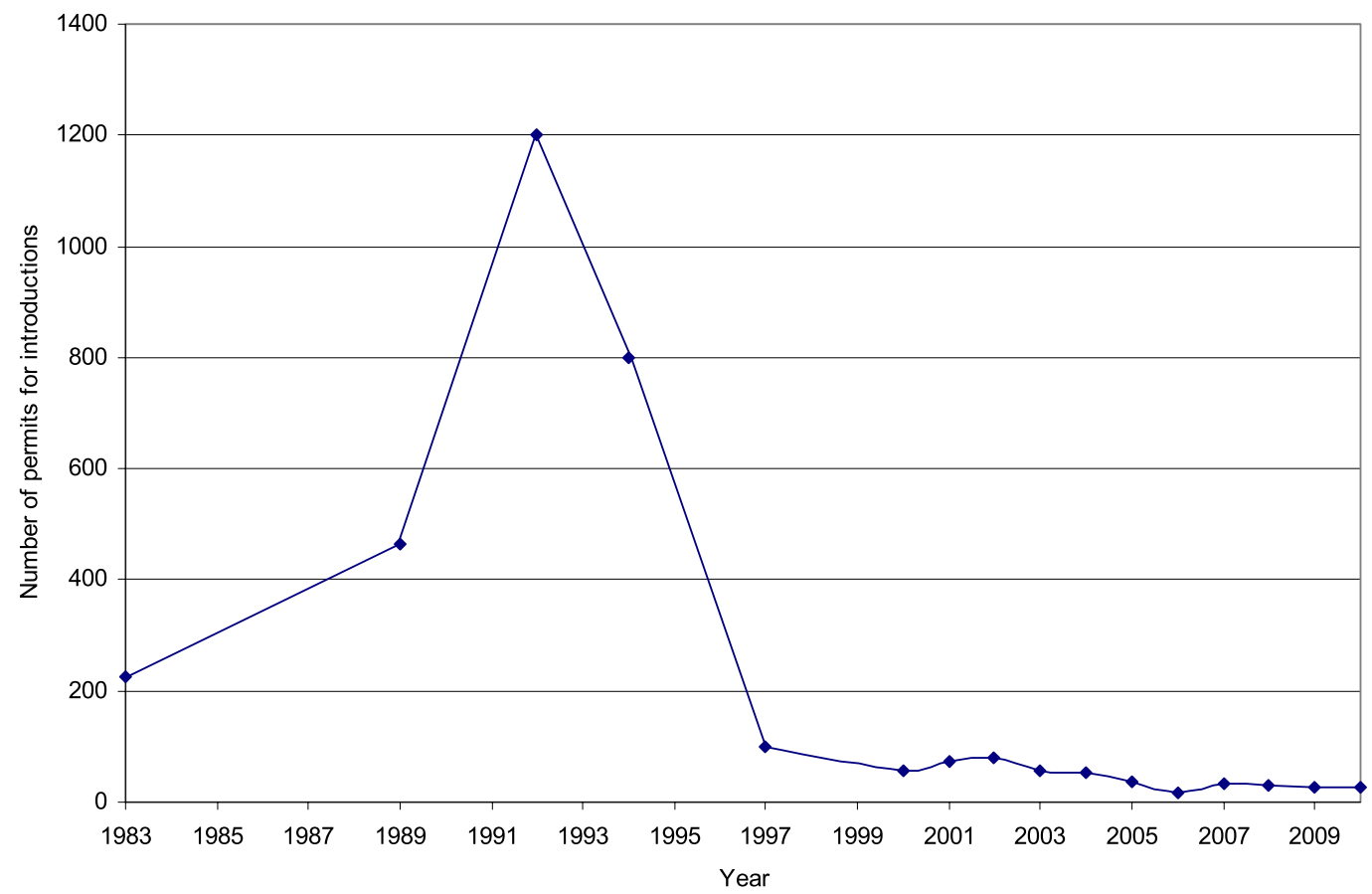

Figure 2

Number of stocking permits of signal crayfish given 1983-2010 by all the Swedish County Administrations $(n=21)$.

\section{Figure 2}

Nombre d'autorisations d'introductions de l'écrevisse signal (1983-2010) dans tous les comtés administratifs suédois $(n=21)$. 


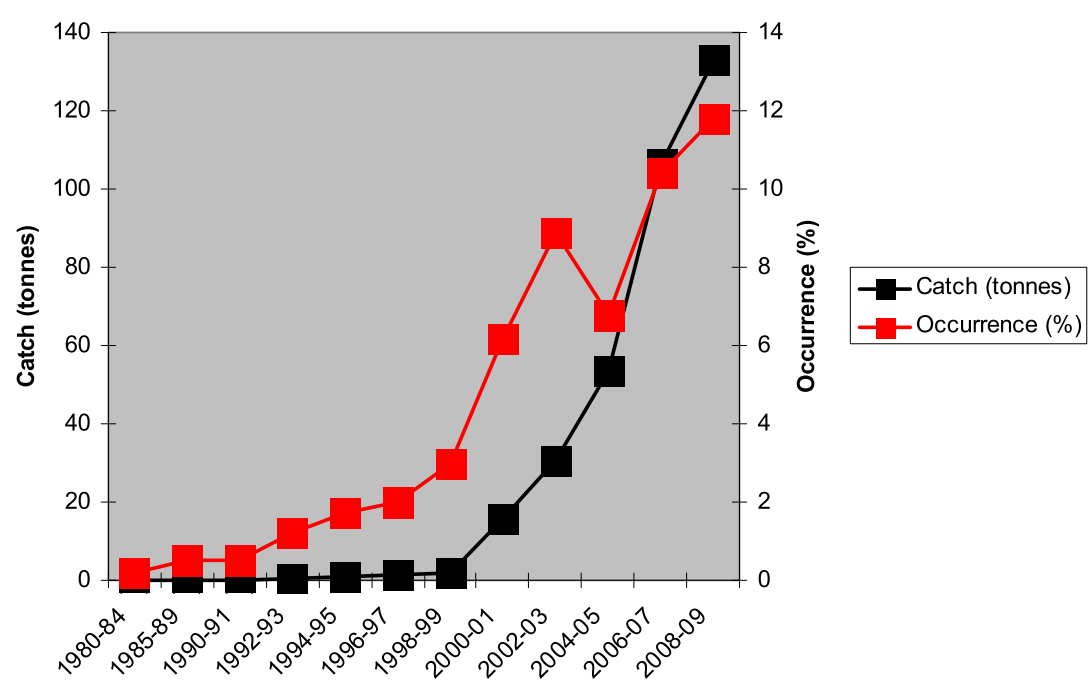

\title{
Figure 3
}

Occurrence (\%) of signal crayfish in electrofishing sites 1980-2009 (data from SERS) and catch (metric tonnes) of signal crayfish by the commercial fishery in Lake Vättern as reported to the Swedish Board of Fisheries.

\author{
Figure 3 \\ Occurrence (\%) de l'écrevisse signal dans les sites de pêches électriques de 1980 à 2009 (données du \\ SERS) et les captures (en tonnes) de l'écrevisse signal par les pêcheurs commerciaux du lac Vättern \\ enregistrées par le bureau suédois des pêcheries.
}

Several factors may have contributed to the rapid spread of signal crayfish in Sweden. Primarily, the large-scale introduction of signal crayfish 1969-1994 has resulted in the occurrence of signal crayfish in a large number of waters, previously empty or inhabited by noble crayfish. This has also made a large number of signal crayfish available for stocking. Previously, signal crayfish for stocking had to be bought from a few suppliers, which meant a stricter control of stocking. Today, this control is harder to fulfil. In almost all Swedish lakes the general fishing rules are strict, granting the fishing rights owner (and a few commercial fishermen) the exclusive rights to fish. An exception is Lake Vättern, Sweden's second largest lake, located in central Sweden. This lake inhabits a very strong populations of signal crayfish, which have increased significantly during recent years (2000-2009). It is also the only lake where fishing for crayfish is open for the public. Due to this live signal crayfish has been available for a large number of people.

The crayfish fishery in Lake Vättern was opened in 1999 for the general public, and all Swedish citizens were allowed to fish for crayfish in the lake during a shorter period and with a limited number of traps. This was quite exceptional since it made Lake Vättern the only lake in Sweden where fishing for crayfish was allowed for all citizens. This has created a huge interest and tens of thousands of people from all over the country take part in this fishery each year. In 1999-2002 there were no restrictions in size of captured crayfish in Lake Vättern, which may have led to an increase of small $(7-10 \mathrm{~cm})$ crayfish, used for restocking or illegal introductions. Unfortunately, no reliable catch statistics are available from the non-commercial fisheries in Sweden. There is however good statistics on the commercial catch by licensed fishermen that can give a good picture of the development of the non-commercial fishery in the lake. The reported catch from the commercial fishery in Lake Vättern increased from an average of $1 \mathrm{t}$ in 1993-1994 to $133 \mathrm{t}$ 2008-2009. The occurrence of crayfish in running waters in Sweden increased along with increasing catches in Lake Vättern (Spearman rank $\rho=0.991, p<0.001, n=12$; Figure 3). If the non-commercial fishery has followed the same trend a substantial amount of live signal crayfish has been available for people from all over the country. 
Although our results may indicate that signal crayfish from Lake Vättern are used for illegal introductions, not all new populations in running waters are due to illegal stocking with crayfish from this lake. Natural migration is often seriously limited by water barriers and by the crayfish own limitations in movement (Martins et al., 2005; Degerman et al., 2009; Bohman and Edsman, submitted), making this explanation unlikely. Signal crayfish is now caught and transported as live animals in many new regions in Sweden. Although the live crayfish are meant to be cooked and consumed, it is easy to catch live signal crayfish, transport them by car, and release them illegally in a whole new water area. All introductions require a stocking permit from the County administrations, but the cost for illegal stocking is low (Gren et al., 2006). The ecological cost may however be substantial.

\section{REFERENCES}

Alm G., 1929. Der Krebs und die Krebspest in Schweden. Zeitschrift für Fisherei, 27, 123-138.

Appelberg M., 1984. Early development of the crayfish Astacus astacus L. in acid water. Rep. Inst. Freshwater Res., 61, 48-59.

Arwidsson I., 1920. Kräftpesten i Sverige. Anteckningar under åren 1909-1919, Meddelanden från Kungliga Lantbruksstyrelsen, $229 \mathrm{p}$.

Bohlin T., Hamrin S., Heggberget T.G., Rasmussen G. and Saltveit S.J., 1989. Electrofishing - theory and practice with special emphasis on salmonids. Hydrobiologia, 173, 9-43.

Bohman P. and Edsman L., to appear. Management and conservation of crayfish in Sweden - results and the way forward. Freshwater Crayfish, 18.

Bohman P. and Edsman L., submitted. Illegal introductions, crayfish plague outbreaks, and the distance to Lake Vättern - two applications of the Swedish Crayfish Database. Freshwater Crayfish.

Bohman P., Edsman L. and Nordwall F., 2006. The effect of the large-scale introduction of signal crayfish on the spread of crayfish plague in Sweden. Bull. Fr. Pêche Piscic., 380-381, 1291-1302.

Cerenius L., Laurent P. and Edsman L., 2002. Protection of natives in a plague situation. Bull. Fr. Pêche Piscic., 367, 909-910.

Degerman E., Sers B. and Magnusson K., 2009. Signalkräftan expanderar i Sverige. Fauna och Flora, 104, 28-32.

Dieguez-Uribeondo J., 2009. Current techniques, approaches and knowledge in diagnosis of crayfish plague and other crayfish diseases. Knowl. Managt. Aquatic Ecosyst., 394-395, 02.

Dieguez-Uribeondo J., Cerenius L., Dyková I., Gelder S., Henntonen P., Jiravanichpaisal P., Lom J. and Söderhäll K., 2006. Pathogens, parasites and ectocommensals. In: Souty-Grosset C., Holdich D.M., Noël P.Y., Reynolds J.D. and Haffner P. (eds.), Atlas of Crayfish in European, Collection Patrimoines Naturels, Muséum national d'Histoire naturelle, Paris.

Edsman L., 2000. Crayfish conservation in Sweden, lessons to learn. In: Rogers D. and Brickland J. (eds.), Crayfish Conference Leeds, Environment agency, Leeds, 19-25.

Edsman L., 2003. 13 misunderstandings about crayfish. In: Taugbol T., Edsman L. and Souty-Grosset C. (eds.), European native crayfish with a special focus on Astacus astacus: linking socioeconomics and conservation, Abstracts.

Edsman L., 2010. Pros and cons with the huge interest in crayfish - Implications for management and conservation in Scandinavia. In: Souty-Grosset C., Grandjean F. and Mirebeau C. (eds.), European Crayfish: food, flagships and ecosystem services, Poitiers, France, Abstracts, $44 \mathrm{p}$.

Edsman L. and Schröder S., 2009. Åtgärdsprogram för Flodkräfta 2008-2013 (Astacus astacus), Fiskeriverket och Naturvårdsverket, Rapport 5955, 67 p.

Fiskeriverket and Naturvårdsverket, 1998. Action plan for the conservation of the noble crayfish in Sweden. In: Järvi T. and Thorell L. (eds.), Fiskeriverket and Naturvårdsverket, Göteborg and Stockholm (in Swedish with English summary).

Fjälling A. and Fürst M., 1985. The introduction of the signal crayfish Pacifastacus leniusculus into Swedish waters: 1969-1984. Information from the Institute of Freshwater Research, Drottningholm, 8, 1-29 (in Swedish with English summary).

Gren I.-M., Bohman P. and Edsman L., 2006. Environmental fraud and social norms: An application to illegal signal crayfish in Sweden. In: ASLO Summer Meeting: Global Challenges Facing Oceanography and Limnology, Victoria, Kanada, Abstracts. 
Häggström Å., 1994. Report of the situation of the crayfish plague in Sweden 1994. Swedish Board of Fisheries, 7 p. (in Swedish).

Lowery R.S. and Holdich D.M., 1988. Pacifastacus leniusculus in North America and Europe, with details of the distribution of the introduced and native crayfish species in Europe. In: Holdich D.M. and Lowery R.S. (eds.), Freshwater Crayfish - Biology, Management and Exploitation, Croom Helm, London, 283-308.

Martins T., Edsman L. and Bohman P., 2005. The present distribution of signal crayfish in west Sweden - natural migration from legally introduced populations or a consequence of unauthorized human mediated spread? In: European crayfish as heritage species - linking research and management strategies to conservation and socio-economics, Abstracts, $24 \mathrm{p}$.

Söderhäll K. and Cerenius L., 1999. The crayfish plague fungus: history and recent advances. Freshwater Crayfish, 12, 11-35.

Taugbol T., 2004. Reintroduction of noble crayfish Astacus astacus after crayfish plague in Norway. Bull. Fr. Pêche Piscic., 372-373, 233-239.

Unestam T., 1972. On the host range and origin of the crayfish plague fungus. Rep. Inst. Freshw. Res., Drottningholm, 52, 199-203. 